\title{
AKTIVITAS ANTIHIPERPIGMENTASI LIKOPEN SECARA IN SILICO
}

\author{
M. D. Widyastuti, N. K. M. Noviyanti, I K. N. S. Sanjaya dan N. M. P. Susanti* \\ Program Studi Farmasi, Fakultas Matematika dan Ilmu Pengetahuan Alam, \\ Universitas Udayana, Jimbaran, Badung, Bali, Indonesia \\ *Email: dekpitsusanti@unud.ac.id
}

\begin{abstract}
ABSTRAK
Hiperpigmentasi disebabkan oleh terakumulasinya melanin yang berlebihan pada kulit sehingga terjadi penggelapan kulit. Hiperpigmentasi ini salah satu penyebab orang kurang percaya diri, sehingga produk kosmetik dipasaran menawarkan solusi antihiperpigmentasi. Senyawa yang umum digunakan pada produk antihiperpigmentasi adalah hidrokuinon Permasalahan penggunaan hidrokuinon terletak pada efek samping yang ditimbulkan yaitu okronosis, genotoksisitas, dan karsinogenik. Tujuan penelitian ini untuk mengetahui potensi likopen sebagai antihiperpigmentasi secara in silico dengan mekanisme penghambatan tirosinase dibandingkan dengan hidrokuinon. Metode yang digunakan adalah molecular docing. Analisis data dilakukan dengan membandingkan energi ikatan yang diperoleh dari likopen dan hidroquinone yang di-docking-kan dengan tirosinase. Energi ikatan dari kedua senyawa tersebut dengan tirosinase secara berturut-turut adalah $-5,18$ dan 4,22. Nilai energi ikatan tirosinase lebih rendah dibandingkan dengan hidrokuinon. Perbandingan energi ikatan dari likopen dan hidroquinone menunjukkan bahwa likopen merupakan senyawa yang memiliki potensi sebagai inhibitor tirosinase secara in silico dengan aktivitas yang lebih tinggi dibandingkan dengan hidrokuinon.
\end{abstract}

Kata kunci: Hiperpigmentasi, Hidrokuinon, Likopen, In Silico

\section{ABSTRACT}

Hyperpigmentation is caused by the accumulation of excessive melanin in the skin resulting in skin merging. Hyperpigmentation is one of the reasons for some people to have lack of confidence, and thus cosmetic products on the market offer solutions as antihyperpigmentation. The compound which commonly used in antihiperpigmentation products is hydroquinone. The problems with the use of hydroquinone are the side effects caused by ochronosis, genotoxicity and carcinogenicity. The aim of this study was to know the potential of lycopene as an in silico antihiperpigmentation by the use of tyrosinase inhibition mechanism compared to hydroquinone. The method used was molecular docking. Data analysis was done by comparing the bonding energy obtained from lycopene and hydroquinone which was docked by tyrosinase. The bonding energy of the two compounds with tyrosinase was -5.18 and -4.22 . The bonding energy of tyrosinase was lower than hydroquinone. The comparison of bonding energy between lycopene and hydroquinone showed that lycopene had the potential as an in silico tyrosinase inhibitor with higher activity compared to hydroquinone.

Keywords: Hyperpigmentation, Hidroquinone, Lycopene, In Silico

\section{PENDAHULUAN}

Paparan sinar matahari berlebih utamanya paparan sinar urtraviolet sangat mudah diperoleh dari aktivitas di luar ruangan dalam kehidupan sehari-hari, utamanya di negara beriklim tropis seperti Indonesia. Paparan sinar urtraviolet berlebih dapat mengakibatkan terjadinya akumulasi melanin (pigemen kulit gelap) pada bagian epidermis, dan dermis kulit (Agustine dan Yenny, 2011).Akumulasi melanin juga dapat diakibatkan oleh penuaan karena pembentukan ROS (reactive oxygen species) secara terus- menerus sebagai hasil dari metabolisme oksidasi seluler (Puspitasari dkk., 2017). Akumulasi melanin pada kulit ini disebut dengan hiperpigemntasi (Agustine dan Yenny, 2011). Hiperpigmentasi adalah kondisi yang mengakibatkan terjadinya masalah penampilan atau estetika (Gazali dkk., 2014), utamanya bagi perempuan, warna kuit yang gelap kerap kali menurunkan rasa percaya diri bagi perempuan.

Obat antihiperpigmentasi yang beredar dipasaran umumnya memiliki mekanisme sebagai inhibitor tirosinase. Hingga saat ini hidrokuinon dengan konsentrasi $4 \%$ dalam 
sediaan adalah inhibitor tirosinase yang paling sering digunakan dalam terapi hiperpigmentasi namun memiliki efek samping okronosis, mengakibatkan genotoksisitas, dan menghasilkan metabolit benzokuinon akibat reaksinya dengan tirosinase yang karsinogenik sehingga pemakaiannya dibatasi (BPOM, 2016; Puspitasari dkk., 2017).

Likopen merupakan senyawa yang memiliki aktivitas antioksidan kuat yaitu 100 kali lebih efektif dibandingkan vitamin $\mathrm{E}$ atau 12500 kali lebih baik dari glutation (Maulida dan Aurkanean, 2010). Antioksidan merupakan senyawa yang mampu mencegah hiperpigmentasi melalui mekanisme penghambatan ROS (Briganti et. al., 2003). Berdasarkan hal tersebut, penelitian ini bertujuan untuk mengetahui potensilikopen sebagai antihiperpigemntasi dengan mekanisme inhibitor tirosinase secara in silico dengan molecular docking dibandingkan dengan hidroquinone.

\section{MATERI DAN METODE}

\section{Bahan}

Bahan yang digunakan untuk penentuan aktivitas tirosinase likopen secara in silico adalah tirosinase yang di-download dari http://www.pdb.org/pdb/home/home.do dengan kode 1WX4. Struktur dari senyawa likopen dan hiroquinone di-download dari https://pubchem.ncbi.nlm.nih.gov.

\section{Peralatan}

Alat yang digunakan untuk uji in silico adalah komputer yang memiliki spesifikasi Windows 1064 bit. Program untuk docking molecular adalah AutoDock Tools 1.5.6,Chimera 1.11.1 untuk preparasi protein, dan Hyper Chem 8 untuk preparasi serta optimasi senyawa uji.

\section{Metode Penelitian Preparasi Protein}

Preparasi protein tirosinase dilakukan mengunaankan software Chimera 1.11.1. Preparasi tirosinase dilakukan dengan memisahkan protein dengan senyawa native ligandnya.

\section{Validasi Metode Docking Molecular}

Native ligand dengan tirosinase yang telah dipreparasi di-docking-kan kembali sebagai tahapan dalam validasi metode. Validasi dilakukan dengan menggunakan Auto Dock Tools 1.5.6. Parameter validasi yang digunakan adalah nilai RMSD (Root Mean Sequare Distance $)<3 \AA$, nilai tersebut menunjukkan protokol diterima dan docking dapat dilakukan.

\section{Optimasi Likopen dan Hidroquinone 3D}

Struktur 3D likopen dan hidroquinone yang telah di-download kemudian dioptimasi menggunakan Hyper Chem 8. Optimasi dilakukan pada senyawa beserta dengan atom hidrogennya. Optimasi dilakukan dengan melakukan kalkulasi single point dan geometri optimasi.

\section{Docking Likopen dan Hidroquinone pada Tirosinase}

Docking dilakukan dengan mengguanakn program Autodock 4.2. Senyawa yang dianalisis didockingkan pada tirosinase yang telah dipreparasi. Hasil dari molecular docking adalah konformasi senyawa dalam berikatan dengan protein target yang memiliki energi ikatan terendah.

\section{Analisis Data Docking Likopen dan Hidroquinone pada Tirosinase}

Hasil molecular docking adalah berupa energi ikatan. Energi ikatan yang diperoleh menggambarkan kekuatan dari ikatan anatara senyawa yang di-docking-kan dengan reseptor. Semakin negatif energi ikatan yang diperoleh, maka makin kuat interaksi senyawa terhadap tirosinase. Hasil energi ikatan yang diperoleh dari likopen dan hidroquinone dibandingkan untuk mengetahui potensi likopen sebagai antihiperpigmentasi.

\section{HASIL DAN PEMBAHASAN}

\section{Optimasi Struktur 3D Senyawa Uji}

Struktur 3D likopen dan hidrokuinon dioptimasi menggunakan program Hyperchem 8 dengan metode kalkulasi semi empiris pada model AM1 (Austin model 1). Keunggulan dari kalkulasi semi empiris yakni memerlukan waktu yang lebih cepat dibandingka dengan $a b$ intio. Model AM1 merupakan model yang sangat akurat karena parameter-parameter yang diperhitungkan meliputi total energi, sifat elektronik, pembentukan panas dan geometri optimasi (Hypercube, 2002), sehingga hasil 
pemodelan AM1 memiliki karakteristik senyawa hasil optimasi lebih mendekati senyawa sintetis (Tahir dkk., 2004). Pada proses optimasi, dilakukan kalkulasi single point dan optimasi geometri untuk memperoleh struktur 3D likopen dan hidrokuinon yang paling stabil dengan energi total terendah. Hasil dari optimasi struktur likopen dan hidrokuinon ditunjukkan pada Gambar 1 dan 2.

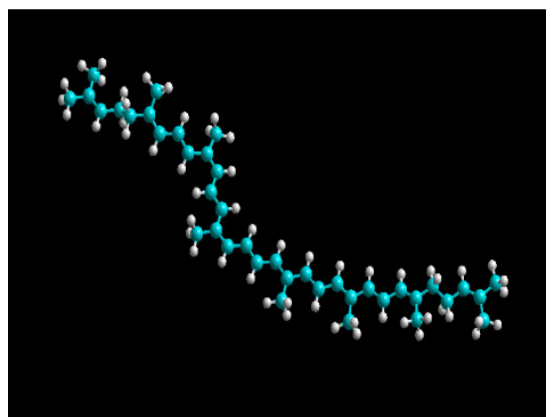

Gambar 1. Struktur Tiga Dimensi Likopen Teroptimasi

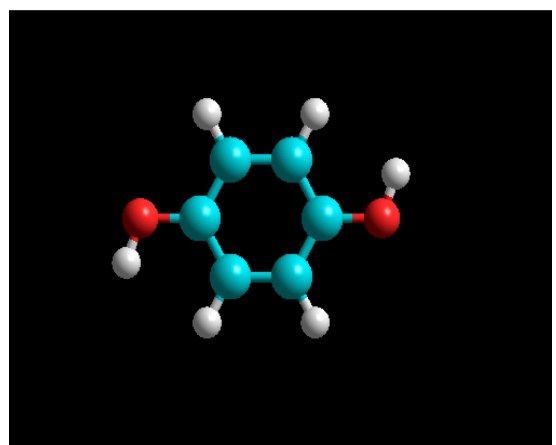

Gambar 2. Struktur Tiga Dimensi Hidrokuinon Teroptimasi

Besar energi total hasil kalkulasi single point likopen sebesar -11310,758379 $\mathrm{kkal} / \mathrm{mol}$ dan hidrokuinon sebesar $1520,843729 \mathrm{kkal} / \mathrm{mol}$. Setelah dilakukan optimasi geometri terjadi penurunan energi struktur, yaitu energi likopen sebesar $11359,0314 \mathrm{kkal} / \mathrm{mol}$ dan energi hidrokuinon sebesar -1522,9466 kkal/mol. Optimasi senyawa ditunjukkan degan terjadinya penurunan energi total senyawa. Nilai energi hasil optimasi semakin rendah menunjukkan senyawa tersebut memiliki interaksi berupa gaya tarik antar atom yang semakin besar sedangkan gaya tolak antar atom menjadi semakin minimum sehingga konformasi senyawa yang diperoleh semakin stabil (Hypercube, 2002).

\section{Preparasi Struktur 3D Protein Target}

Tirosinase dipreparasi dengan memisahkan native ligand dari struktur protein menggunakan Chimera 1.11.1, yang mana melalui proses ini maka akan diperoleh struktur protein tirosinase tanpa native ligand. Tirosinase merupakan protein yang terdiri dari 4 rantai yang sama yaitu rantai A, B, C dan D (Ismaya et.al., 2011), sehingga untuk proses optimasi dapat dipilih salah satu rantai tersebut, yang mana pada penelitian ini digunakan rantai A. Pemilihan rantai dilakukan untuk memfokuskan pemilihan sisi aktif dari protein target.

Optimasi dilakukan dengan pemisahan native ligand dengan struktur rantai protein. Pemisahan native ligand dari struktur rantai protein bertujuan untuk menyediakan pocket yang akan digunakan sebagai ruang tempat berikatan likopen dan hidrokuinon pada protein target. Selain diperoleh struktur protein tanpa native ligand, struktur native ligand yang terpisah dari protein juga diperoleh. Struktur rantai protein yang telah terpisah dari native ligand dan struktur native ligand dapat dilihat pada Gambar 3.

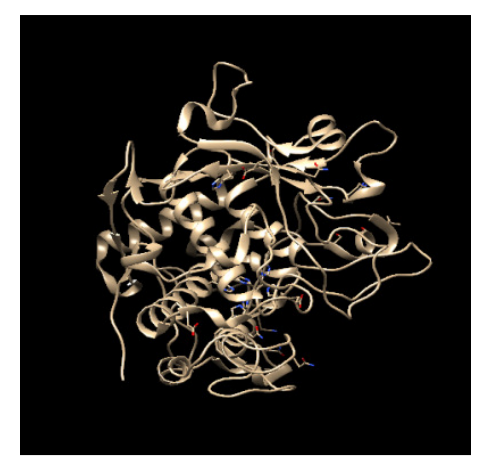

(a)

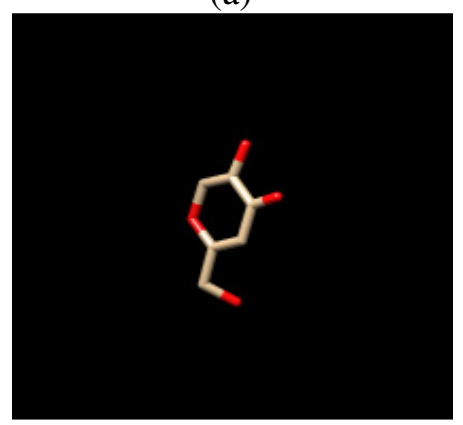

(b)

Gambar 3. Struktur Rantai Protein Tirosinase Tanpa Native Ligand (a) Native Ligand Tirosinase (b). 
Pada proses preparasi protein, juga dilakukan eliminasi dari molekul air $\left(\mathrm{H}_{2} \mathrm{O}\right)$ disekitar struktur protein, hal tersebut bertujuan agar molekul air tidak mengganggu proses docking, sehingga dapat dipastikan yang berinteraksi hanya ligan dengan protein (Tjahyono dan Hamzah, 2013). Native ligand dan protein yang telah dipreparasi kemudian disimpan dalam format file .pbd.

\section{Validasi Metode Molecular Docking}

Validitas metode molecular docking diketahui dengan cara men-docking-kan kembali (redocking) native ligand pada protein terget menggunakan program AutoDockTools 1.5.6. Proses validasi metode molecular docking yang pertama dilakukan adalah menambahkan atom hidrogen pada protein target yang sudah memiliki pocket cavity. Penambahan hidrogen bertujuan untuk menyesuaikan suasana docking agar mendekati suasana $\mathrm{pH}$ di dalam tubuh (Drie, 2005). Selain itu, penambahan atom hidrogen memiliki tujuan untuk memunculkan kembali atom hidrogen pada makromolekul sehingga ikatan hidrogen yang terbentuk dapat teramati (Sastry et al., 2013).

Dalam validasi metode molecular docking, dilakukan juga pengaturan grid box yang akan menjadi ruang untuk native ligand membentuk konformasi ketika di-docking-kan dengan protein target dilakukan setelah protein. Grid box merupakan tempat dari ligand untuk berinteraksi dengan residu asam amino pada binding site protein target. Penentuan grid box dilakukan untuk mengetahui titik koordinat pada binding site dari suatu protein. Pengaturan grid box yang dilakukan adalah pengaturan koordinat grid center dan pengaturan grid size (Rachmania dkk., 2016). Parameter validasi dalam molecular docking berupa nilai RMSD (Root Mean Square Deviation). RMSD menunjukkan perbandingan konformasi native ligand hasil docking dengan konformasi native ligand hasil pengukuran kristalografi (Saputri dkk., 2016). Batas nilai RMSD yang dapat diterima adalah $\leq 3 \AA ̊$ (Jain dan Nicholls, 2008). Nilai RMSD yang diperoleh untuk protein tirosinase sebesar $0,79 \AA$ Á. Berdasarkan hasil tersebut, metode yang digunakan dapat dikatakan valid sehingga proses docking likopen dan hidrokuinon dapat dilakukan. Visualisasi interaksi antara protein tirosinase dan native ligand-nya ditunjukkan pada Gambar 4.

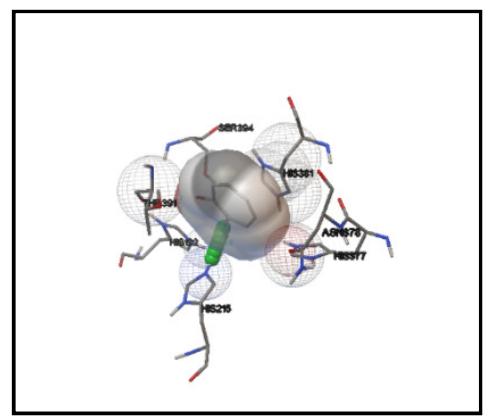

Gambar 4.Visualisasi interaksi antara Tirosinase dengan Native Ligand-nya.

\section{Docking Likopen dan Hidrokuinon pada Tirosinase}

Senyawa likopen dan hidrokuinon yang telah dioptimasi kemudian di-dockingkan pada tirosinase menggunakan program Autodock 4.2 dengan ukuran grid box dan koordinat yang diperoleh saat validasi metode. Penggunaan ukuran grid box dan koordinat yang sama pada saat validasi dilakukan untuk memastikan bahwa senyawa uji di-dockingkan tepat pada sisi aktif dari tirosinase sesuai dengan hasil validasi. Metode yang digunakan dalam docking likopen dan hidrokuinon sama dengan ketika validasi metode, yaitu semirigid, yang mana senyawa diatur dalam keadaan fleksibel dan protein target dalam keadaan rigid, sehingga memungkinkan senyawa untuk mencapai konformasi optimum untuk berikatan dengan sisi aktif pada protein target.

Proses docking menghasilkan nilai energi ikatan antara senyawa uji dengan protein taget. Energi ikatan menunjukkan afinitas likopen dan hidrokuinon pada protein target. Semakin negatif energi ikatan yang diperoleh, ikatan yang terbentuk antara likopen dan hidrokuinon dengan tirosinase akan semakin stabil.

Nilai energi ikatan yang diperoleh antara likopen dan hidrokuinon dengan tirosinase berturut-turut $-5,18$ dan $-4,22$ $\mathrm{kkal} / \mathrm{mol}$. Hal ini menunjukkan bahwa likopen dengan tirosinase memiliki ikatan yang lebih stabil dibandingkan dengan hidrokuinon dengan tirosinase. Sehingga berdasarkan hasil penelitian ini dapat diprediksi bahwa likopen memiliki aktivitas sebagai antihiperpigmentasi karena memiliki afinitas dengan tirosinae. Interaksi antara likopen dengan tirosinase 
dapat menghambat pembentukan melanin, dikarenakan interaksi terjadi pada sisi aktif dari tirosinase yang mengakibatkan aktivitas inhibitor. Visualisasi interaksi antara likopen dan hidrokuinon dengan protein tirosinase ditunjukkan pada Gambar 5.

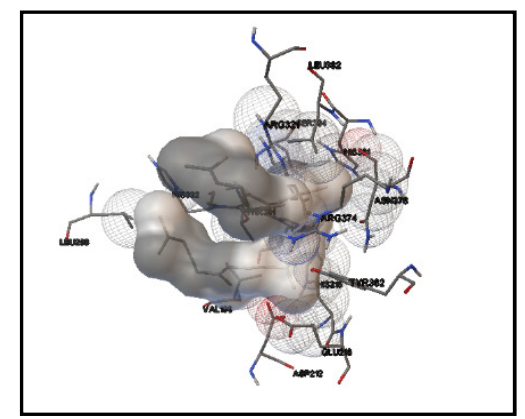

(a)

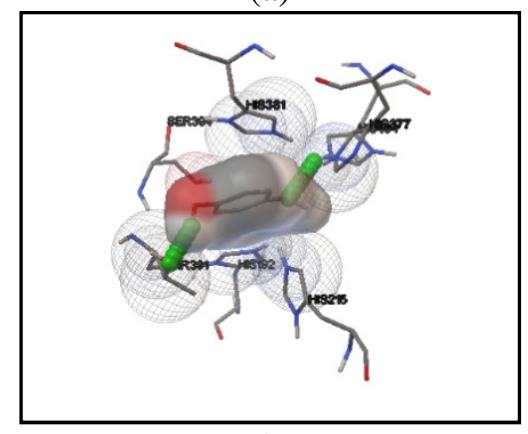

(b)

Gambar 5. Visualisasi Interaksi Likopen dengan Tirosinase (a) dan Hidrokuinon dengan Tirosinase (b).

\section{SIMPULAN DAN SARAN}

\section{Simpulan}

Likopen berpotensi sebagai antihiperpigmentasi secara in silico dan berpotensi sebagai senyawa alternatif untuk antihiperpigmentasi.

\section{Saran}

Uji aktivitas secara in silico merupakan suatu uji pendahuluan yang memprediksi interaksi ligan dan reseptor. Konfirmasi aktivitas melalui uji in vitro dan in vivo perlu dilakukan untuk memastikan aktivitas.

\section{DAFTAR PUSTAKA}

Cindric, I. J., Kunstic, M., Zeiner, M., Stingeder, G., and Rusak, G., 2011, Sampel Preparation Methods for the Determination of the Antioxidative Capacity of
Apple Juice, Croat. Chem. Acta, 84 (3): 435-438

Dalimartha, S., 2008, Atlas Tumbuhan Obat Indonesia, Jilid 5, Pustaka Bunda, Jakarta

Drie, J.H.v., 2005, Pharmacophore-Based Virtual Screening : A Practical Perspective, Alvarez, J. and Schoicet, B., Virtual Screening in Drug Discovery, Taylor and Francis Group, Boca Raton, 157205.

Gunawan, S.G., Setiabudy, R., Nafrialdi, dan Elysabeth, 2007, Farmakologi dan Terapi, $5^{\text {th }}$ ed., Departemen Farmakologi dan Terapeutik Fakultas Kedokteran, Universitas Indonesia, Jakarta

Guyton, A. C., dan Hall, J. E., 1997, Buku Ajar: Farmakologi Kedokteran, $9^{\text {th }}$ ed., a.b. Setiawan, I., Tengadi K.A., dan Santoso, A., Penerbit Buku Kedokteran EGC, Jakarta.

Hypercube, 2002,Hyper Chem Release 7: Tools for Molecular Modeling, Hypercube Incorporation, Ontario.

Ismaya, W.T., Rozeboom, H.J., Wejin, A., Mes, J.J., Fusetti, F., Wichers, H.J. and Dijkstra, B.W. 2011. Crystal Structure pf Agaricus bisporus Mushroom Tyrosinase: Identity of The Tetramer Subunits and Interaction with Tropolone. Biochemistry. 50:5477-5486.

Jain, A.N. and Nicholls, A., 2008, Recommendations for Evaluations of Computational Methods, J. Comput. Aided Mol. Des., 22:133-139.

Rachmania, R.A., Supandi, dan Cristina, F.A.D., 2016, Analisis Penambatan Molekul Senyawa Flavonoid Buah Mahkota Dewa (Phaleria macrocarpa (Scheff.) Boerl.) pada Reseptor $\alpha$ Glukosidase sebagai Antidiabetes, Pharmacy, 13(2):239-251.

Saputri, K.E., Fakhmi, N., Kusumaningtyas, E., Priyatama, D. dan Santoso, B., 2016, Docking Molekular Potensi Anti Diabetes Melitus Tipe 2 Turunan Zerumbon Sebagai Inhibitor Aldosa Reduktase 
Dengan Autodock-Vina, Chimica et Natura Acta, 4(1):16-20.

Sastry, G.M., Adzhigirey, M., Day, T., Annabhimoju, R. and Sherman, W., 2013, Protein and Ligand Preparation : Parameters, Protocols, and Influence on Virtual Screening Enrichments, $J$. Comput. Aided Mol. Des., 27(3):221-234.

Tahir, I., K. Wijaya, Falah, I.I., dan Damayanti, R., 2004, 'Pemodelan Molekul Senyawa MycosporineLike Amino Acids (MAAs-Like) sebagai Senyawa Penyerap Sinar UV', dipresentasikan pada Seminar Nasional Hasil Penelitian MIPA di Semarang, 4 Desember.

Tjahjono, D.H., dan Hamzah, N., 2013, Studi Hubungan Kuantitatif StrukturAktivitas, Fitur Farmakofor, dan Docking Molekuler Senyawa Turunan Pirazolo-[3,4-d]Pirimidin sebagai Inhibitor Mer Tirosin Kinase, Acta Pharmaceutica Indonesia, 38(1):1-10.
Tjandra, O., Rusliati, R., dan Zulhipri, 2011, Uji Aktifitas Antioksidan dan Profil Fitokimia Kulit Rambutan Rapiah (Nephelium lappaceum), Karya Ilmiah, UPT Penerbitan dan Percetakan UNS, Solo

Zainol, Q., Hidayat, E. M., dan PeryogaS. U., 2014,Antipyretic Effect of Cinnamomum burmannii (Nees \& T.Nees) Blume Infusion in Feverinduced Rat Models, Althea Medical Journal, 1 (2): 81-85. 